\title{
Shift Scheduling Optimization: A Real-Life Underground Transportation Example
}

\author{
Hafsa Nur Öztürk ${ }^{1 *}$, H. Ediz Atmaca ${ }^{2}$, Hatice Erdoğan Akbulut $^{3}$, Esra Aktaş ${ }^{4}$

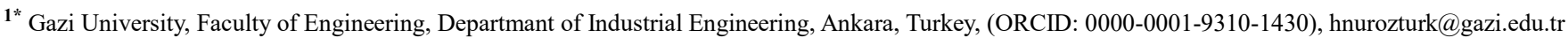 \\ ${ }^{2}$ Gazi University, Faculty of Engineering, Departmant of Industrial Engineering, Ankara, Turkey, (ORCID: 0000-0002-0671-3939), hediz@gazi.edu.tr \\ ${ }^{3}$ Antalya Bilim University, Faculty of Engineering and Natural Science, Departmant of Industrial Engineering, Antalya, Turkey, (ORCID: 0000-0001-9393-0466), \\ hatice.erdogan@antalya.edu.tr \\ ${ }^{4}$ Gümüşhane University, Faculty of Health Sciences, Departmant of Occupational Health and Safety, Gümüşhane, Turkey, (ORCID: 0000-0001-6064-6485), \\ esra.aktas@gumushane.edu.tr
}

(2nd International Conference on Applied Engineering and Natural Sciences ICAENS 2022, March 10-13, 2022)

(DOI: 10.31590/ejosat.1082151)

ATIF/REFERENCE: Öztürk, H. N., Atmaca, H.E., Erdoğan Akbulut, H. \& Aktaş, E. (2022). Shift Scheduling Optimization: A RealLife Underground Transportation Example. European Journal of Science and Technology, (34), 332-335.

\begin{abstract}
Personnel scheduling is basically a type of scheduling that determines which employee will work and when, taking into account the needs of the industry and employees. Personnel scheduling is intertwined with shift scheduling problems in shift systems. In many industries, the assignment of employees to shifts during the day, the determination of relief breaks and meal breaks are an important factor for shift scheduling while meeting the changing workforce needs. The main purpose of this study is to schedule the shifts of the machinists of Ankaray, which is one of the underground transportation networks of Ankara, the capital of Turkey, in the transportation sector where people serve people. In the study, shift scheduling models in the literature were examined and Aykin's optimal shift scheduling with multiple break windows was taken as a basis. The model divides the working hours into two shifts during the day and finds the number of employees required for each shift. In addition, it also determines the relief break and lunch break times for each employee. As a result, the current situation was analyzed and a comparison was made with the results on the established optimization model. Cost minimization is at the root of the problem, so it is concretely shown how this model will contribute in real life.
\end{abstract}

Keywords: Shift Scheduling, Personnel Scheduling, Transportation, Underground Transportation Optimization, Integer Programming.

\section{Vardiya Çizelgeleme Optimizasyonu: Gerçek Hayat Yer Altı Taşımacılığı Örneği}

Öz

Personel çizelgeleme temelde sektörün ve çalışanların ihtiyaçları dikkate alınarak hangi çalışanın ne zaman çalışacağını belirleyen bir çizelgeleme türüdür. Personel çizelgeleme, vardiyalı çalışılan sistemlerde vardiya çizelgeleme problemleri ile iç içedir. Pek çok sektörde, gün içinde vardiyalara çalışanların atanması, dinlenme ve yemek molalarının belirlenmesi, değişen iş gücü ihtiyaçlarını karşılarken vardiya çizelgelemesi için önemli bir faktördür. Bu çalışmanın temel amacı, insanların insanlara hizmet ettiği ulaşım sektöründe, Türkiye'nin başkenti Ankara'nın yeraltı ulaşım ağlarından biri olan Ankaray'ın makinistlerinin vardiyalarını planlamaktır. Çalışmada, literatürdeki vardiya çizelgeleme modelleri incelenmiş ve Aykin'in çoklu mola pencereli optimal vardiya çizelgelemesi çalışması esas alınmıştır. Model, çalışma saatlerini gün içinde iki vardiyaya bölerek her vardiya için gereken çalışan sayısını bulmaktadır. Ayrıca her çalışan için dinlenme molası ve yemek molası saatlerini de belirlenmektedir. Sonuç olarak mevcut durum analiz edilmiş ve kurulan optimizasyon modeli üzerinde sonuçlarla karşılaştırma yapılmıştır. Problemin temelinde maliyet minimizasyonu bulunmaktadır, dolayısıyla bu modelin gerçek hayata nasıl katkı sağlayacağı somut olarak gösterilmektedir.

Anahtar Kelimeler: Vardiya Çizelgeleme, Personel Çizelgeleme, Toplu Taşıma, Yeraltı Taşıma Optimizasyonu, Tam Sayılı Programlama.

\footnotetext{
* Corresponding Author: hnurozturk@gazi.edu.tr
} 


\section{Introduction}

Science has had the concept of scheduling for many years. Although this concept has been around for years, Henry Gantt's Gantt chart would popularize it (Hyatt and Weaver, 2006). Although scheduling has been in our lives for many years, it also appears with a wide variety of concepts such as personal scheduling, shift scheduling, workflow scheduling, vehicle scheduling etc.

In shift jobs, personnel scheduling and shift scheduling are intertwined. In personnel scheduling, it is decided which personnel will work where and when, in shift scheduling, it is decided how many personnel will work in which shift. Aykin's (1996) study named 'optimal shift scheduling with multiple break windows', which also forms the basis of this study, includes the basic constraints for shift scheduling. Aykin's study is based on the constraints of Dantzig (1954) 'A Comment on Edie's Traffic Delays at Toll Booths'.

Today, optimal solution methods and heuristic algorithms are used to solve scheduling problems. Katrancı and Organ (2021) developed and solved an integer model for scheduling the shifts of firefighters in their study. Pandey et al., (2021) in their study, they handled the shift scheduling problem for a retail store and used an iterative solution approach consisting of three stages. These solution approaches are respectively; deterministic finite automata (DFA), a mixed-integer linear programming (MILP) and heuristic algorithm. A'lvarez et al., (2020) The approach they propose in their studies, unlike other studies in the literature, tries to minimize the levels of overstaffing and understaffing. Das and Yadav (2020) in their study, they specify the number of people who will deliver for a hyper-local food delivery organization. They developed a simple integer programming model.

\section{Material and Method}

In Ankaray, one of the underground lines in the capital of Turkey, the shift scheduling problem was solved by minimizing the cost by using real-life data.

While constructing the model, relief breaks and meal break times were taken into consideration. Accordingly, periods of 15 minutes each and dividing an hour into 4 equal parts were used in the model. Ankaray's working hours are between 6 a.m.- 12 p.m. and the system works in 2 shifts. Therefore, there are 72 periods in the model. The first 6 working periods are shown in Table [1] as an example.

Table 1. Working Hours Corresponding to Periods

\begin{tabular}{|c|c|}
\hline Periods & Working Hours \\
\hline 1 & 06.00 [a.m.]-06.15 [a.m.] \\
\hline 2 & 06.15 [a.m.]-06.30 [a.m.] \\
\hline 3 & 06.30 [a.m.]-06.45 [a.m.] \\
\hline 4 & 06.45 [a.m.]-07.00 [a.m.] \\
\hline 5 & 07.00 [a.m.]-07.10 [a.m.] \\
\hline 6 & 07.15 [a.m.]-07.35 [a.m.] \\
\hline
\end{tabular}

In the working order of the underground, the time windows for relief breaks and lunch breaks are clear and it is a time period of one and a half hours. Therefore, each working hour and break hour in each shift corresponds to a period.

\subsection{Current Situation Analysis}

Underground transportation is carried out between 6 a.m. and 12 p.m. When the current working style of Ankaray is examined, it is observed that it works in 2 shifts. Each shift has 8 hours of work in and as shown in Table [2] it includes 2 relief breaks which takes 15 minutes and one meal breaks which takes half-hour. The current working hours and how many machinists working are shown in Table [3].

Table 2. Types and Durations of Breaks

\begin{tabular}{|c|c|}
\hline Types of Breaks & Duration \\
\hline $1^{\text {st }}$ Relief Break & 15 min. \\
\hline Meal Break & 30 min. \\
\hline $2^{\text {nd }}$ Relief Break & 15 min. \\
\hline
\end{tabular}

Table 3. Current Working Hours in Each Shift

\begin{tabular}{|c|c|c|}
\hline Shift Type & Working Hours & $\begin{array}{c}\text { Number of } \\
\text { Employees }\end{array}$ \\
\hline $1^{\text {st }}$ Shift & $\begin{array}{c}06.00 \text { [a.m.] - } \\
03.00[\text { p.m.] }\end{array}$ & 12 \\
\hline $2^{\text {nd }}$ Shift & $\begin{array}{c}03.00 \text { [p.m.] - } \\
00.00[\text { a.m.] }\end{array}$ & 13 \\
\hline
\end{tabular}

The number of mechanics required for each hour varies during working hours. The reason for this is that the density of the underground line is not constant during the day. Fig. [1] shows the number of mechanics required for each hour.

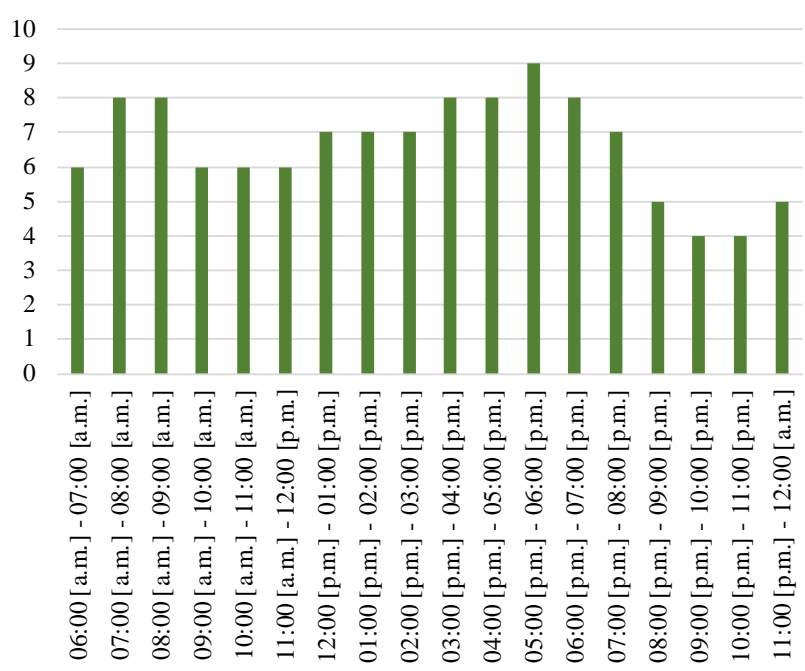

Fig. 1 Number of Machinists Needed

\subsection{Mathematical Model}

In this study, while establishing the mathematical model, the Aykin's (1996) study 'optimal shift scheduling with multiple break windows' was taken as a basis. The purpose of the mathematical model is to minimize the total machinist cost. This objective will also minimize the number of machinists assigned to each shift.

Sets:

$m$ : sets of number of shifts where $j=1 \ldots m$,

$n$ : sets of number of periods where $i=1 \ldots n$,

$T_{1 i}$ : sets of shifts for which period $\mathrm{i}$ is a break start time within the time windows for the first relief break, 
$T_{L i}$ : sets of shifts for which period $\mathrm{i}$ is a break start time within the time windows for the meal break,

$T_{2 i}$ : sets of shifts for which period $i$ is a break start time within the time windows for the second relief break,

$B_{1 j}$ : sets of planning periods in which a machinist working shift $\mathrm{j}$ may start his/her first relief break,

$B_{L j}$ : sets of planning periods in which a machinist working shift $\mathrm{j}$ may start his/her meal break,

$B_{2 j}$ : sets of planning periods in which a machinist working shift $\mathrm{j}$ may start his/her second relief break.

\section{Parameters:}

$C_{j}$ : cost of machinist which works shift $\mathrm{j}$,

$A_{i, j}:\left\{\begin{array}{l}1 \text { if machinist working in the shift } \mathrm{j} \text { is active in period } \mathrm{i} \\ 0 \text { o. w., }\end{array}\right.$

$D_{i}$ : demand of machinist in period $\mathrm{i}$.

\section{Decision Variables:}

$x_{j}$ : number of machinists assigned to work in shift $\mathrm{j}$,

$u_{j, i}$ : number of machinists assigned to shift $\mathrm{j}$ and taking the first relief break in period $i$,

$w_{j, i}:$ number of machinists assigned to shift $\mathrm{j}$ and taking the meal break in period $i$,

$v_{j, i}:$ number of machinists assigned to shift $\mathrm{j}$ and taking the second relief break in period i.

\section{Objective Function:}

minimize $\sum_{J=1}^{m} C_{j} x_{j}$

\section{Constrains:}

$\sum_{j=1}^{m} A_{i, j} x_{j}-\sum_{j \in T 1 i} u_{j, i}-\sum_{j \in T L(i-1)} w_{j, i-1}-\sum_{j \in T L i} w_{j, i}-$

$\sum_{j \in T 2 i} v_{j, i} \geq D_{i}$

$x_{j}-\sum_{i \in B 1 j} u_{j, i}=0$

$x_{j}-\sum_{i \in B L j} w_{j, i}=0$

$\forall \mathrm{j}=1 \ldots \mathrm{m}$

$x_{j}-\sum_{i \in B 2 j} v_{j, i}=0$

$\forall \mathrm{j}=1 . \mathrm{m}$

$x_{j}, u_{j, i}, w_{j, i}, v_{j, i} \geq 0$ and integer

$\forall \mathrm{j}=1 . \mathrm{m}$

$\forall \mathrm{j}=1 . \mathrm{m}$

$\forall \mathrm{i}=1 \ldots \mathrm{n}$

Constrain [1] simply ensures that the number of machinists assigned to the relevant period is greater than or equal to the machinist needed in that period. The [2nd] [3rd] and [4th] constraints, respectively, equalize the number of machinists assigned to shift $\mathrm{j}$ to the number of machinists by giving first relief break, meal break and second relief break in that shift. The last constraint ensures that the decision variables are greater than or equal to 0 and are integers.

\section{Results and Discussion}

The model outputs how many machinists should work in each shift and the number of machinists who need to take relief breaks and lunch breaks for each period. In this context, the number of machinists required to go to the first relief break, meal break and second relief break for each period is shown in Tables [4], [5], [6], [7], [8] and [9], respectively.

Table 4. Number of Machinists Required to Go to the First Relief Break in First Shift

\begin{tabular}{|c|c|}
\hline Working Hours & $\begin{array}{c}\text { Number of Machinists } \\
\text { to Take a First Relief } \\
\text { Break in First Shift }\end{array}$ \\
\hline 07.15 [a.m.]-07.30 [a.m.] & 2 \\
\hline 07.30 [a.m.]-07.45 [a.m.] & 2 \\
\hline 07.45 [a.m.]-08.00 [a.m.] & - \\
\hline 08.00 [a.m.]-08.15 [a.m.] & 2 \\
\hline 08.15 [a.m.]-08.30 [a.m.] & 2 \\
\hline 08.30 [a.m.]-08.45 [a.m.] & 2 \\
\hline
\end{tabular}

Table 5. Number of Machinists Required to Go to the Meal Break in First Shift

\begin{tabular}{|c|c|}
\hline Working Hours & $\begin{array}{c}\text { Number of Machinists } \\
\text { to Take a Meal Break } \\
\text { in First Shift }\end{array}$ \\
\hline 09.45 [a.m.]-10.00 [a.m.] & 2 \\
\hline 10.00 [a.m.]-10.15 [a.m.] & - \\
\hline 10.15 [a.m.]-10.30 [a.m.] & 4 \\
\hline 10.30 [a.m.]-10.45 [a.m.] & - \\
\hline 10.45 [a.m.]-11.00 [a.m.] & 4 \\
\hline 11.00 [a.m.]-11.15 [a.m.] & - \\
\hline
\end{tabular}

Table 6. Number of Machinists Required to Go to the Second Relief Break in First Shift

\begin{tabular}{|c|c|}
\hline Working Hours & $\begin{array}{c}\text { Number of Machinists } \\
\text { to Take a Second Relief } \\
\text { Break in First Shift }\end{array}$ \\
\hline 12.15 [p.m.]-12.30 [p.m.] & 3 \\
\hline 12.30 [p.m.]-12.45 [p.m.] & 3 \\
\hline 12.45 [p.m.]-01.00 [p.m.] & 1 \\
\hline 01.00 [p.m.]-01.15 [p.m.] & - \\
\hline 01.15 [p.m.]-01.30 [p.m.] & - \\
\hline 01.30 [p.m.]-01.45 [p.m.] & 3 \\
\hline
\end{tabular}

Table 7. Number of Machinists Required to Go to the First Relief Break in Second Shift

\begin{tabular}{|c|c|}
\hline Working Hours & $\begin{array}{c}\text { Number of Machinists } \\
\text { to Take a First Relief } \\
\text { Break in Second Shift }\end{array}$ \\
\hline 03.15 [p.m.]-03.30 [p.m.] & - \\
\hline 03.30 [p.m.]-03.45 [p.m.] & 3 \\
\hline 03.45 [p.m.]-04.00 [p.m.] & - \\
\hline 04.00 [p.m.]-04.15 [p.m.] & 5 \\
\hline 04.15 [p.m.]-04.30 [p.m.] & - \\
\hline 04.30 [p.m.]-04.45 [p.m.] & 5 \\
\hline
\end{tabular}


Table 8. Number of Mmachinists Required to Go to the Meal Break in Second Shift

\begin{tabular}{|c|c|}
\hline Working Hours & $\begin{array}{c}\text { Number of Machinists } \\
\text { to Take a Meal Break } \\
\text { in Second Shift }\end{array}$ \\
\hline 05.45 [p.m.]-06.00 [p.m.] & 3 \\
\hline 06.00 [p.m.]-06.15 [p.m.] & - \\
\hline 06.15 [p.m.]-06.30 [p.m.] & 5 \\
\hline 06.30 [p.m.]-06.45 [p.m.] & - \\
\hline 06.45 [p.m.]-07.00 [p.m.] & 5 \\
\hline 07.00 [p.m.]-07.15 [p.m.] & - \\
\hline
\end{tabular}

Table 9. Number of Machinists Required to Go to the Second Relief Break in Second Shift

\begin{tabular}{|c|c|}
\hline Working Hours & $\begin{array}{c}\text { Number of Machinists } \\
\text { to Take a Second Relief } \\
\text { Break in Second Shift }\end{array}$ \\
\hline 08.15 [p.m.]-08.30 [p.m.] & - \\
\hline 08.30 [p.m.]-08.45 [p.m.] & - \\
\hline 08.45 [p.m.]-09.00 [p.m.] & - \\
\hline 09.00 [p.m.]-09.15 [p.m.] & - \\
\hline 09.15 [p.m.]-09.30 [p.m.] & 4 \\
\hline 09.30 [p.m.]-09.45 [p.m.] & 9 \\
\hline
\end{tabular}

In the current situation of the work, the number of people working in the 1st shift is 12 , and the number of people working in the 2 nd shift is 13 . The total number of employees during the day is 25 . As a result of the optimization model applied, the number of workers in the 1st shift was reduced to 10 , while the number of workers in the 2 nd shift remained constant at 13 . During the day, the number of employees was reduced to 23 and a profit was obtained from a working force of 2 people. If this number is considered on the basis of daily working time, a daily gain of 16 hours has been achieved. If the optimal result is considered on the basis of costs, a daily profit of 32.7 dollars is obtained when the gross wage is 360 dollars. In this context, weekly, monthly and annual earnings are shown in Fig [2].

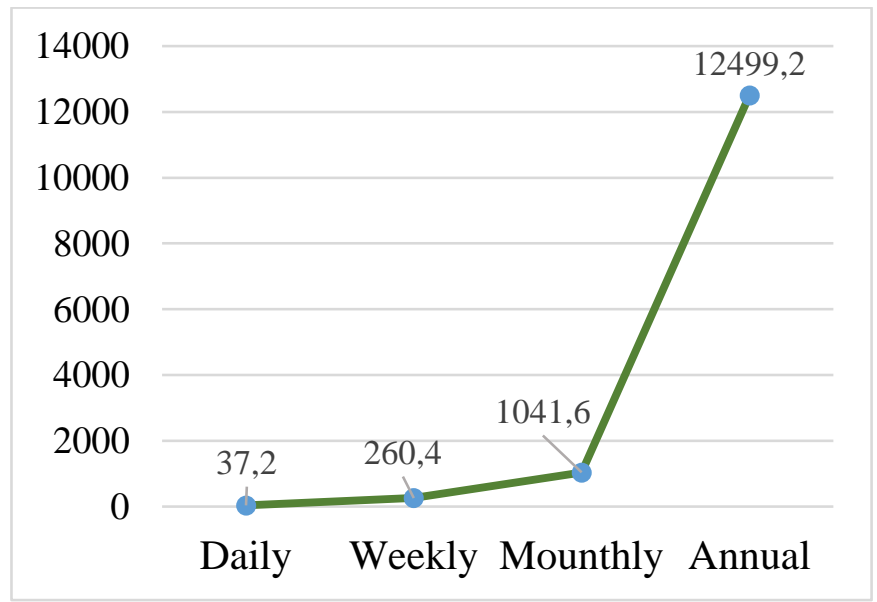

Fig. 2 Profits in Dollars

This study has been done for a 2-shift underground transportation system and minimizes the number of machinists assigned to each shift by minimizing the cost. The study contributes to the literature as it is done with real-life data. In future studies, the model can be developed by changing the number of shifts, adding other costs to the objective function, maximizing profits for the objective function, and adding new constraints depending on the conditions of the sectors.

\section{Conclusions}

This study has been solved by using real-life data for the shift scheduling problem found in the literature. Relief breaks and meal breaks are of great importance in order to increase the productivity of the employees and therefore the efficiency of the system. This issue, which is emphasized in this study, combined with real-life data, reveals how much profit can be made by actually making this shift scheduling. When the current situation and the proposed situation are compared, it is seen that 2 less employees are needed every day. Although it may sound small on a daily basis, it creates a visible effect when considered on an annual basis.

\section{References}

A'lvarez, E., Ferrer, J., Munoz, J. C. and Henao, C. A., (2020). 'Efficient shift scheduling with multiple breaks for full-time employees: A retail industry case,' Computers \& Industrial Engineering, vol. 150, Oct. 2020.

Aykin T. (1996). 'Optimal Shift Scheduling with Multiple Break Windows,' Management Science, vol. 42, pp. 591-602, Apr. 1996.

Dantzig, G. B., (1954). "A Comment on Edie's 'Traffic Delays at Toll Booths'," Oper. Res., 2, 3 (1954), 339-341.

Das, D., and Yadav, C., (2020). 'A framework of hiring strategy for manpower hiring in a hyper-local food delivery organization' Journal of Advances in Management Research, vol. 18, pp. 113-135, July, 2020.

Hyatt, C., and Weaver, P. (2006). 'A Brief History of Scheduling.' Melbourne, Australia: Mosaic Project Services Pty Ltd.

Katranc1, A., and Organ A., (2021). 'Integer Programming Approach for Solution of Fire Fighters Schedule Problem,' Pamukkale University Journal of Business Research, vol. 8, pp. 131-149, May, 2021.

Pandey, P., Gajjar, H. and Shah B. J., (2021). 'Determining optimal workforce size and schedule at the retail store considering overstaffing and understaffing costs' Computers \& Industrial Engineering, vol.161, Aug. 2021. 